\title{
Isolation and Characterization of Bacteriophage against Methicillin Resistant Staphylococcus aureus
}

Mariem N Mohammed-Ali ${ }^{1 *}$ and Nidham M. Jamalludeen ${ }^{1}$

Department of Microbiology, College of Medicine, University of Basrah, Basrah, Iraq

\begin{abstract}
Methicillin resistant Staphylococcus aureus (MRSA) is a major human pathogen responsible for several life threatening conditions. MRSA have the ability to acquire resistance to several antimicrobial agents and phage therapy is one potential option to treat this pathogen. The aim of the study was to isolate and characterize bacteriophages effective against a wide range of methicillin-resistant Staphylococcus aureus (MRSA). A mixture of ten MRSA isolates was used for the isolation of phage from wastewater treatment plants. Three phages were selected for further characterization. All three phages belong to the Siphoviridae family and have long non-contractile flexible tails. The three phages showed a wide host range against $S$. aureus. Phages $\phi S A 1$ and $\phi S A 2$ were resistant to a $\mathrm{pH}$ range from 4-10 while $\phi S A 3$ has a $\mathrm{pH}$ range from 3-11. DNA from all three phages was resistant to digestion by endonuclease enzymes such as EcoRI and Accl. There was a high degree of mosaicism among the three virulent phages and with their ancestor phages of Siphoviridae due to their non-uniform access to the common genetic pool by horizontal gene transfer and recombination. Since some of the staphylococcal toxins are phage encoded, the presence of genes for such toxins was tested by performing polymerase chain reaction and all three phages lacked genes for any of the staphylococcal toxins, including staphylococcal enterotoxins (sea, seb, sec and see), exfoliating toxins (eta and etb) and the toxic shock syndrome toxin (tst), therefore these bacteriophage are suitable candidates for future use in phage therapy against MRSA.
\end{abstract}

Keywords: Staphylococcus aureus; Phage therapy; MRSA phage; Siphoviridae; Anti-restriction mechanism; Mosaicism

\section{Introduction}

Methicillin-resistant Staphylococcus aureus (MRSA) is a worldwide pathogen that is responsible for a variety of diseases ranging from soft tissue and skin infections to life threatening conditions such as pneumonia, bacteremia and sepsis [1]. MRSA is one of the major human pathogens that may cause community and hospital acquired infections [2]. These organisms are frequently resistant to most of the commonly used antimicrobial agents, including $\beta$-lactam antibiotics [3]. The emergence and spread of strains resistant to oxacillin, methicillin and even vancomycin has made therapy of these multi drug resistant bacteria a global challenge [4]. MRSA has a wide variety of virulence factors that include structural and secreted factors [5]. These factors include superantigens, cytolytic toxins, exoenzymes and miscellaneous proteins [6]. Superantigens are a group of powerful immuno-stimulatory proteins implicated in a variety of human diseases including gastroenteritis and toxic shock syndrome [7].

One possible approach to treatment of methicillin resistant $S$. aureus is phage therapy, defined as the application of phage to selectively reduce or eliminate susceptible pathogens from specific environments [8]. Phage therapy may be a suitable alternative to antibiotic treatment due to the high specificity of and effectiveness against multi drug resistant bacteria $[9,10]$. The use of bacteriophages in clinical medicine was first introduced by Félix d'Herelle [11]. Many therapeutic phages have been isolated against MRSA, most of which belong to the Myoviridae family such as the well-known phage K and MR-10 [12,13]. Since all tailed phages are believed to share common ancestors, a high frequency of chimeric and mosaic structures can be observed among different tailed phage families due to their access to a common genetic pool $[14,15]$. Such mosaicism has resulted in a high degree of similarity among phages in both nucleic acids and proteins [16]. The main aims of this study were to isolate a set of bacteriophages effective against a wide range of MRSA isolates and characterize these phages according to their morphological features, host range, endonuclease enzyme digestion pattern, molecular identification, the presence of undesirable toxin encoding genes.

\section{Materials and Methods}

\section{Culture media and chemicals}

The following media and chemicals were used for the study: brain heart infusion agar (Salucea, Netherlands), brain heart infusion broth (HIMEDIA, India), blood agar (HIMEDIA, India), mannitol salt agar (OXOID, England), Mueller Hinton agar (HIMEDIA, India), Agar agar (HIMEDIA, India), agarose (Bio Basic, Canada), peptone (DIFCO, USA), beef extract (OXOID, England), yeast extract (Sigma-Aldrich, Switzerland), sodium chloride (Sigma-Aldrich, Switzerland), sodium hydroxide (Sigma-Aldrich, Switzerland), potassium dihydrogen phosphate (Sigma-Aldrich, Switzerland), Gelatin (BDH, England), barium chloride (Hopkins and Williams Limited, England), Gram stain (HIMEDIA, India), catalase test reagent (HIMEDIA, India), coagulase plasma (HIMEDIA, India), API Staph (bioMérieux, France), EcoRI (promega, USA), AccI (BioLabs, New England), sulfuric acid (BDH, England), hydrochloric acid (BDH, England), tris-(hydroxymethyl)aminomethane ( $\mathrm{pH}$ 7.5) (Riedel-deHaën, Germany), Chloroform (Sigma-Aldrich, Switzerland), glycerol (Chem-supply, Australia), absolute ethanol (BDH, England), nuclease free water (Promega, USA),

*Corresponding author: Mariem N. Mohammed-Ali, Department of Microbiology College of Medicine, University of Basrah, Basrah, Iraq, Tel: 9641886 8520; E-mail: mary.wadi91@gmail.com

Received October 30, 2015; Accepted December 28, 2015; Published December 30, 2015

Citation: Mohammed-Ali MN, Jamalludeen NM (2015) Isolation and Characterization of Bacteriophage against Methicillin Resistant Staphylococcus aureus. J Med Microb Diagn 5: 213. doi:10.4172/2161-0703.1000213

Copyright: (c) 2015 Mohammed-Ali MN, et al. This is an open-access article distributed under the terms of the Creative Commons Attribution License, which permits unrestricted use, distribution, and reproduction in any medium, provided the original author and source are credited. 
ethidium bromide (Fisher, USA), bromophenol blue (Fisher, USA), TBE buffer (Promega, USA), TE buffer (Promega, USA), (Bioanalyse, USA), cefoxitin disc $(30 \mu \mathrm{g})$ (Bioanalyse, USA), DNA ladder marker (100-1000 bp) (Promega, USA) and DNA ladder marker (100-10000 bp (KAPA, USA).

\section{Sample collection}

A total of 100 isolates of staphylococci were obtained from various clinical sources such as skin, anterior nares, ear wound, sputum, blood and urine all according to standard methods of sample collection [17]. The isolates were randomly collected from healthcare workers, hospital patients and patient's escorts at Al-Sadar hospital, Al-Basra General Hospital, Ibn Ghazwan Hospital and day care centers in Basra.

\section{MRSA identification}

Staphylococcus aureus isolates were identified by standard methods described [17]. Staphylococcus aureus isolates isolates were characterized as methicillin resistant (MRSA) using the cefoxtin disc ( $30 \mu \mathrm{g})$ diffusion method [18]. The diameter of the zone of inhibition was measured and the results were interpreted according to CLSI criteria [19].

\section{Isolation of bacteriophage}

Bacteriophages were isolated from raw sewage samples obtained from Al-Sadar hospital raw sewage in Basra according to previously described methods [20,21]. A $200 \mathrm{ml}$ volume of fresh sewage was mixed with $20 \mathrm{ml}$ of bacteriophage broth [peptone $(100 \mathrm{~g} / \mathrm{L})$, beef extract $(30 \mathrm{~g} / \mathrm{L})$, yeast extract $(50 \mathrm{~g} / \mathrm{L})$, sodium chloride $(25 \mathrm{~g} / \mathrm{L})$, potassium dihydrogen phosphate $(80 \mathrm{~g} / \mathrm{L})], 20 \mathrm{ml}$ of a mixture of 2 MRSA strains (ATCC 25923 and ATCC 29213) in broth culture (optical density at 600 $\mathrm{nm}(\mathrm{OD} 600=1.4)$ and $20 \mathrm{ml}$ of BHI broth were aseptically added to a $1 \mathrm{~L}$ flask and incubated at $37^{\circ} \mathrm{C}$ for $24 \mathrm{~h}$ with shaking ( $55 \mathrm{rpm}$ ). After incubation, the mixture was centrifuged at $4500 \mathrm{xg}$ for $15 \mathrm{~min}$ and the supernatant was transferred into a clean flask and then filtered through a sterile $0.45 \mu \mathrm{m}$ membrane filter (chm, Spain). The phage titre was determined by serial dilution in which $100 \mu$ volumes of the filtrate was mixed with $100 \mu \mathrm{l}$ of broth culture containing MRSA in a test tube and incubated at $37^{\circ} \mathrm{C}$ for $20 \mathrm{~min}$ then $3 \mathrm{ml}$ of top agarose $(7.0 \mathrm{~g} / \mathrm{L})$ was added, the tube contents were then mixed and poured onto the surface of a BHI agarose plate and allowed to harden for a few minutes and then incubated at $37^{\circ} \mathrm{C}$ for $16 \mathrm{~h}$. Next day, the plates were examined for the presence of plaques. A control tube containing bacteria and $3 \mathrm{ml}$ of top agarose without filtrate was also cultured on a BHI agarose plate.

A sterile Pasteur pipette with a rubber bulb was used to gently suction a well-isolated plaque. The pipette contents were transferred into a tube containing $1 \mathrm{ml}$ of SM buffer $\left(5.8 \mathrm{~g} / \mathrm{L} \mathrm{NaCl}, 2 \mathrm{~g} / \mathrm{L} \mathrm{MgSO}_{4} 7 \mathrm{H}_{2} \mathrm{O}, 50 \mathrm{ml} / \mathrm{L}\right.$ of $1 \mathrm{M}$ Tris $\mathrm{pH} 7.5,5 \mathrm{ml} / \mathrm{L}$ of $2 \%$ gelatin) and 1 drop of chloroform was added to each tube. The tubes were held at room temperature for $1-2 \mathrm{~h}$ to allow the bacteriophage particles to diffuse out of the agar. The phage titre was determined by the soft agarose overlay method and finally the phages were stored at $4^{\circ} \mathrm{C}$ until stocks were prepared.

\section{Bacteriophage stock preparation}

Bacteriophage stock was prepared according to Sambrook et al. [21]. A $100-\mu$ l volume of bacteriophage suspension was incubated with $100 \mu \mathrm{l}$ of the selected host bacterium for $20 \mathrm{~min}$ at $37^{\circ} \mathrm{C}$, and then $3 \mathrm{ml}$ of top agarose was added, mixed and poured onto a $\mathrm{BHI}$ agarose plate which was incubated for $6-8 \mathrm{~h}$ at $37^{\circ} \mathrm{C}$. A $2 \mathrm{ml}$ volume of SM buffer was then added to each plate in order to harvest the phages and then was transferred into tubes containing $0.2 \mathrm{ml}$ of chloroform. The mixture was kept at $4 \quad{ }^{\circ} \mathrm{C}$ for $2-3 \mathrm{~h}$ and gently vortexed and centrifuged at $4500 \mathrm{x} \mathrm{g}$ for $15 \mathrm{~min}$. The supernatant was recovered and a drop of chloroform was added. The supernatant was filtered through a sterile $0.45 \mu \mathrm{m}$ membrane filter (chm, Spain) and the filtrate was stored at $4{ }^{\circ} \mathrm{C}$ and the titres of the phage stocks were determined by plaquing 10 -fold dilutions using the soft agarose overlay method. The phage stock was purified for further studies by layering $4 \mathrm{ml}$ of $5 \%$ glycerol solution in SM buffer over $40 \%$ glycerol and adding the sample on the top, followed by ultracentrifugation at $25000 \mathrm{xg}$, for $2 \mathrm{~h}$ at $4{ }^{\circ} \mathrm{C}$. The phage-containing pellet was resuspended in $1 \mathrm{ml} \mathrm{SM}$ buffer.

\section{Electron microscopy}

Phage particles were negatively stained with $2 \%$ uranyl acetate (Sigma-Aldrich, Switzerland) on carbon-coated copper grid using standard procedures. TEM images were captured in Zeiss EM10C (Zeiss, Germany) at Khajeh Nasir Toosi University of Technology (IRAN). Three phages that were isolated were classified according to the International Committee on Taxonomy of Viruses ICTV [22].

\section{Host range}

The host range of each of the isolated bacteriophages was determined against a number of MRSA isolates as described by Jamalludeen et al., [20]. A lawn of a single MRSA isolate was inoculated on a BHI agar plate and the plate was divided into four squares by marking the surface of the plate. The plate was left to dry for a few minutes and then $10 \mu \mathrm{l}$ of each phage suspension $(109 \mathrm{pfu} / \mathrm{ml})$ was dropped in the center of each square except for one square which was left as control. Following incubation at $37^{\circ} \mathrm{C}$ for $24 \mathrm{~h}$, these plates were examined for lysis. A clear zone in the bacterial lawn was recorded as complete lysis.

\section{Resistance of phages to acidity and alkalinity}

Resistance of phages to acidity and alkalinity was done according to Jamalludeen et al. [20]. A $100 \mu \mathrm{l}$ volume of phage suspension (109 pfu/ $\mathrm{ml}$ ) was added to $900 \mu \mathrm{l}$ of saline adjusted to a specific $\mathrm{pH}$. The mixture was incubated at $37^{\circ} \mathrm{C}$ for $16 \mathrm{~h}$. A control sample (phage suspension and normal saline, $\mathrm{pH} 7.2$ ) was also incubated at $37^{\circ} \mathrm{C}$ for $16 \mathrm{~h}$. The titre of the surviving phages was determined by plaquing 10 -fold dilutions by the soft agarose overlay method.

\section{Extraction of bacteriophage DNA}

The bacteriophage DNA was extracted using the QIAprep Spin M13 kit (QIAGEN, Germany) and according to the manufacturer's instruction. DNA was detected with the Nano drop (Optizen, Korea) and was visualized by agarose gel electrophoresis [21].

\section{Restriction endonuclease enzyme digestion patterns}

A (5-10) $\mu$ l volume of DNA was digested with EcoRI and AccI enzymes according to the manufacturer's instructions.

\section{Molecular identification of bacteriophage}

In an attempt for molecular identification of the three phages, conserved genomic sequences of Staphylococcus aureus phage type 3A 11, 77, 187 and Twort like phages representing serogroups A, B, F, L and $\mathrm{D}$ were used. Each conserved sequence encodes a certain protein such as head protein, major capsid protein, packaging protein, tail protein or tail fiber protein [23]. Taq PCR master mix used and was supplied by Bioneer (Korea); the primers were designed by Macrogen (Korea). The primer sequences and their lengths are shown in Table 1.

\section{Detection of possible toxin genes by polymerase chain reaction $(\mathrm{PCR})$}

Undesirable genes including staphylococcal enterotoxins and exfoliating toxins as well as toxic shock syndrome toxin of the isolated 
Citation: Mohammed-Ali MN, Jamalludeen NM (2015) Isolation and Characterization of Bacteriophage against Methicillin Resistant Staphylococcus aureus. J Med Microb Diagn 5: 213. doi:10.4172/2161-0703.1000213

Page 3 of 6

phages were searched by using QIAGEN multiplex PCR kit (QIAGEN, Germany) using a thermo cycler from Eppendorf (mastercycler, personal 5332, Germany) and according to the manufacturer's instructions. The primers were designed for this study by Eurogentec (Belgium). A $100 \mu \mathrm{M}$ $(100 \mathrm{pmol} / \mu \mathrm{l})$ stock of each primer was prepared according to the technical data sheet for each primer and kept in TE buffer at $-70^{\circ} \mathrm{C}$. Staphylococcus aureus specific genes, primers and their exact sequence as well as the size of the amplified product (bp) are listed in Table 2 [24].

\section{Results}

\section{Bacteriophage isolation}

The isolation of bacteriophage from sewage was successful on the first attempt in October 2014 (Figure 1). Initially 20 phages were isolated and of these about 8 phages were tested for their host range. Out of 8 phages only three bacteriophages ( $\phi S A 1, \phi S A 2$, and $\phi S A 3)$ were selected for further characterization for showing a strong lytic activity against all MRSA isolates. The titre of the three bacteriophages $(\phi S A 1, \phi S A 2$, and $\phi S A 3)$ was $\left(5 \times 10^{12}, 2 \times 10^{11}\right.$ and $\left.4 \times 10^{13}\right)$ respectively. A stock of each of the three bacteriophage sample was prepared and purified. All three phages produced clear large to medium sized plaques (4-6 $\mathrm{mm}$ in diameter) when propagated on MRSA isolate.

\section{Morphology of bacteriophage}

The appearance of the three phages by transmission electron microscopy is shown in Figure 2. All three phages have an icosahedral head and a long thin non-contractile flexible tail with tail fibers. Based on their morphology all three phages belong to the family Siphoviridae (order Caudovirales).

The dimensions of the three phages are shown in Table 3. Five images of each phage were measured and the mean values were recorded. All phages have long non contractile flexible tail ranging from $159 \mathrm{~nm}$ to $167 \mathrm{~nm}$ in length.

\section{Host range}

The host range of bacteriophage samples was determined against 100 isolates of methicillin resistant Staphylococcus aureus (MRSA). All three phages showed lytic activity against all 100 MRSA isolates. The characteristic clear zone of inhibition is shown in Figure 3.

\section{Resistance of bacteriophage to acidity and alkalinity}

Differences between the three phages in the $\mathrm{pH}$ range in which they were active were observed. All phages were resistant to $\mathrm{pH} 4$ to $\mathrm{pH} 9$. Phages $\phi S A 1$ and $\phi S A 2$ were also resistant to $\mathrm{pH} 10$ while $\phi S A 3$ was resistant to $\mathrm{pH} 3$ (Table 4).

\section{Restriction endonuclease enzyme digestion patterns}

All three phages were highly refractory to restriction by EcoRI and $A c c$ I endonucleases enzymes. No migrating fragments could be detected (data not shown).

\begin{tabular}{|c|c|c|c|c|c|}
\hline Phage type & Sero-group & Primer & Primer sequence (5'-3') & PCR product length (bp) & Sequence coding for \\
\hline 3A-like phage & A & $\begin{array}{l}\text { SGA1 } \\
\text { SGA2 }\end{array}$ & $\begin{array}{l}\text { TATCAGGCGAGAATTAAGGG } \\
\text { CTTTGACATGACATCCGCTTGAC }\end{array}$ & 744 & Tail fibers \\
\hline 11-like phage & $\mathrm{B}$ & $\begin{array}{l}\text { SGB1 } \\
\text { SGB2 }\end{array}$ & $\begin{array}{l}\text { ACTTATCCAGGTGGYGTTATTG } \\
\text { TGTATTTAATTTCGCCGTTAGTG }\end{array}$ & 405 & Hypothetical tail protein \\
\hline \multirow[t]{3}{*}{ 77-like phage } & $\mathrm{F}$ & $\begin{array}{l}\text { SGF1 } \\
\text { SGF2 }\end{array}$ & $\begin{array}{l}\text { CGATGGACGGCTACACAGA } \\
\text { TTGTTCAGAAACTTCCCAACCTG }\end{array}$ & 155 & Hypothetical tail protein \\
\hline & $\begin{array}{l}\text { Sub-group } \\
\text { Fa }\end{array}$ & $\begin{array}{l}\text { SGFa1 } \\
\text { SGFa2 }\end{array}$ & $\begin{array}{l}\text { TACGGGAAAATATTCGGAAG } \\
\text { ATAATCCGCACCTCATTCCT }\end{array}$ & 548 & Packaging protein \\
\hline & $\begin{array}{l}\text { Sub-group } \\
\text { Fb }\end{array}$ & $\begin{array}{l}\text { SGFb1 } \\
\text { SGFb2 }\end{array}$ & $\begin{array}{l}\text { AGACACATTAAGTCGCACGATAG } \\
\text { TCTTCTCTGGCACGGTCTCTT }\end{array}$ & 147 & Packaging protein \\
\hline $\begin{array}{l}\text { 187-like } \\
\text { phage }\end{array}$ & $\mathrm{L}$ & $\begin{array}{l}\text { SGL1 } \\
\text { SGL2 }\end{array}$ & $\begin{array}{l}\text { GCTTAAAACAGTAACGGTGACAGTG } \\
\text { TGCTACATCATCAAGAACACCTGG }\end{array}$ & 648 & $\begin{array}{l}\text { Hypothetical capsid } \\
\text { protein }\end{array}$ \\
\hline $\begin{array}{l}\text { Twort-like } \\
\text { phage }\end{array}$ & $\mathrm{D}$ & $\begin{array}{l}\text { SGD1 } \\
\text { SGD2 }\end{array}$ & $\begin{array}{l}\text { TGGGCTTCATTCTACGGTGA } \\
\text { GTAATTTAATGAATCCACGAGAT }\end{array}$ & 331 & Major capsid protein \\
\hline
\end{tabular}

Table 1: Staphylococcal phage type, sero-group, primer sequence, PCR product length (bp) and type of protein.

\begin{tabular}{|c|c|c|c|}
\hline Gene & Primer & Oligonucleotide sequence (5'-3') & Size of amplified product (bp) \\
\hline sea & $\begin{array}{l}\text { GSEAR-1 } \\
\text { GSEAR-2 }\end{array}$ & GGTTATCAATGTGCGGGTGG CGGCACTTTTTTCTCTTCGG & 102 \\
\hline seb & $\begin{array}{l}\text { GSEBR-1 } \\
\text { GSEBR-2 }\end{array}$ & GTATGGTGGTGTAACTGAGC CCAAATAGTGACGAGTTAGG & 164 \\
\hline sec & $\begin{array}{l}\text { GSECR-1 } \\
\text { GSECR-2 }\end{array}$ & AGATGAAGTAGTTGATGTGTATGG CACACTTTTAGAATCAACCG & 451 \\
\hline sed & $\begin{array}{l}\text { GSEDR-1 } \\
\text { GSEDR-2 }\end{array}$ & CCAATAATAGGAGAAAATAAAAG ATTGGTATTTTTTTTCGTTC & 278 \\
\hline see & $\begin{array}{l}\text { GSEER-1 } \\
\text { GSEER-2 }\end{array}$ & AGGTTTTTTTCACAGGTCATCC CTTTTTTTTTCTTCGGTCAATC & 209 \\
\hline eta & $\begin{array}{l}\text { GETAR-1 } \\
\text { GETAR-2 }\end{array}$ & GCAGGTGTTGATTTAGCATT AGATGTCCCTATTTTTGCTG & 93 \\
\hline etb & $\begin{array}{l}\text { GETBR-1 } \\
\text { GETBR-2 }\end{array}$ & ACAAGCAAAAGAATACAGCG GTTTTTGGCTGCTTCTCTTG & 226 \\
\hline tst & GTSSTR-1 GTSSTR-2 & АССССTGTTCССTTATCATC TTTTCAGTATTTGTAACGCC & 326 \\
\hline
\end{tabular}

Table 2: Staphylococcus aureus specific genes, primers and their exact sequence as well as the predicted size of the amplified product (bp). 


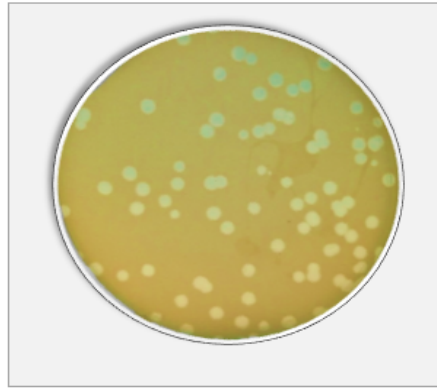

Figure 1: Plaques caused by bacteriophage $\phi S A 1$.

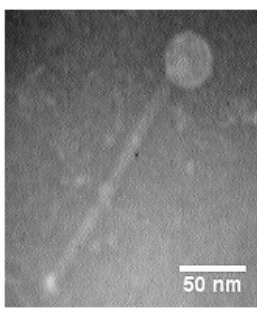

ФSA1

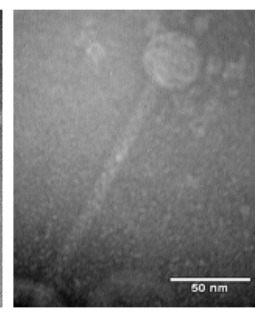

ФSA2

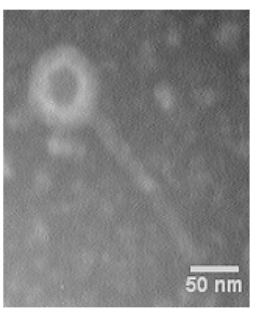

ФSA3
Figure 2: Electron microscopy images of phages $\phi S A 1, \phi S A 2$ and $\phi S A 3$. All phages have long non contractile flexible tails. Bar $=50 \mathrm{~nm}$.

\begin{tabular}{|c|c|c|c|c|}
\hline Phage & \multicolumn{2}{|c|}{ Head dimensions $(\mathbf{n m})$} & \multicolumn{2}{c|}{ Tail dimensions $(\mathbf{n m})$} \\
\hline & Length & Width & Length & Width \\
\hline \$SA1 & 39 & 37 & 167 & 9 \\
\hline \$SA2 & 42 & 39 & 160 & 10 \\
\hline \$SA3 & 50 & 52 & 159 & 16 \\
\hline
\end{tabular}

Table 3: Estimated dimensions of phages $\phi S A 1, \phi S A 2$ and $\phi S A 3)$. Each value is the mean of five independent measurements.

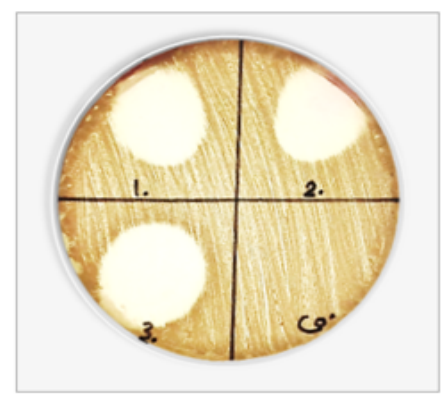

Figure 3: Spot test of phages ( $\phi S A 1, \phi S A 2$ and $\phi S A 3$ ) against an MRSA isolate showing a clear zone of inhibition. $C O=$ control with no phage added.

\begin{tabular}{|c|c|c|c|}
\hline $\mathbf{p H}$ range & \multicolumn{3}{|c|}{ Titre of phages that survived (pfu/ml) } \\
\hline & $\mathbf{\phi S A} 1$ & $\mathbf{\phi S A 2}$ & $\boldsymbol{\phi S A 3}$ \\
\hline 1 & ND* & ND & ND \\
\hline 2 & $\mathrm{ND}$ & $\mathrm{ND}$ & $\mathrm{ND}$ \\
\hline 3 & $2 \times 10^{2}$ & $1 \times 10^{2}$ & $3 \times 10^{5}$ \\
\hline $4-9$ & $10^{8}$ & $10^{8}$ & $10^{9}$ \\
\hline 10 & $1 \times 10^{2}$ & $2 \times 10^{2}$ & $3 \times 10^{4}$ \\
\hline 11 & $\mathrm{ND}$ & $\mathrm{ND}$ & $1 \times 10^{1}$ \\
\hline Control & $10^{9}$ & $10^{9}$ & $10^{9}$ \\
\hline
\end{tabular}

Table 4: Titre of phages ( $\phi S A 1, \phi S A 2$ and $\phi S A 3$ ) after exposure to a range of $p H$ from 1 to 11 .

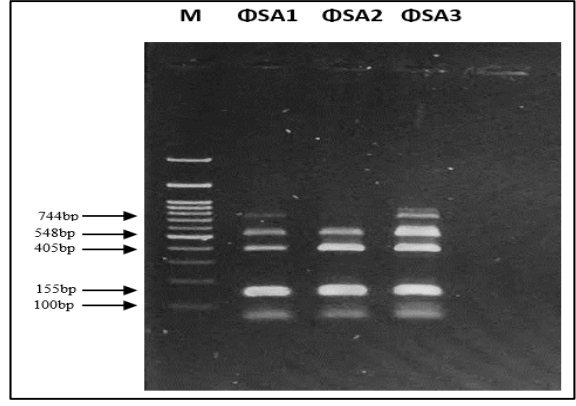

Figure 4: Multiplex PCR showing the presence of amplicons for gene sequences for 3 proteins common to all three samples and the presence of gene sequences for tail fibers (744 bp) in $\phi S A 1$ and $\phi S A 3$.

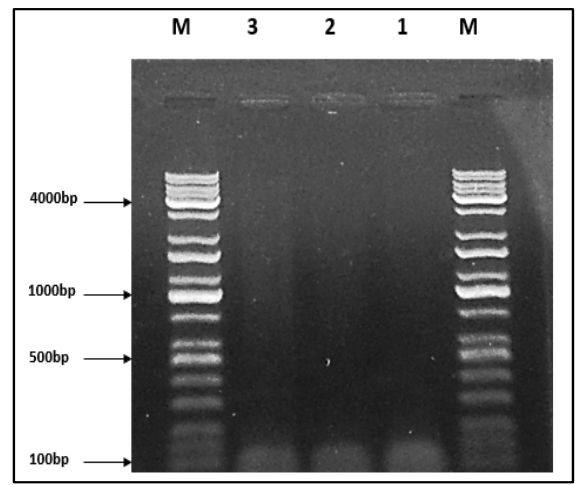

Figure 5: Multiplex PCR for detection of genes for staphylococcal toxins: sea (102 bp), seb (164 bp), sec (451 bp), sed (278 bp), see (209 bp), eta (93 bp), etb $(226 \mathrm{bp})$ and tst (326 bp). None of these genes were present. Marker (M) is 10 Kb KAPA Universal Ladder.

\section{Molecular identification of bacteriophage}

Based on the multiplex PCR results 4 genes out of 7 were detected The PCR products were 155 bp, 405 bp, 548 bp and 744 bp) (Figure 4). These genes are common among staphylococcal phages of Siphoviridae family sero-groups A, B and F which include mostly temperate phages infecting Staphylococcus aureus.

\section{Multiplex PCR for detection of possible staphylococcal toxins}

The PCR results showed that all three phages do not encode for any of the staphylococcal toxins investigated, which consist of staphylococcal enterotoxins (sea, seb, sec and see), exfoliating toxins (eta and etb) and the toxic shock syndrome toxin (tst) (Figure 5).

\section{Discussion}

The aim of the study was to isolate and characterize bacteriophages that have lytic activity against MRSA. Phages are known to be the most abundant viruses in the environment [25]. They are widely spread and can appear in many different environments including marine and soil environments [26,27]. Waste-water treatment plant was considered as a potential source of phages in the current study. The isolation of Siphoviridae phages was successful from the first attempt with high phage titre $\geq 10^{10}$ since these phages are known for their ability to withstand adverse conditions due to their morphology $[28,29]$.

Based on the morphological features of the bacteriophages observed by electron microscopy all three phages belong to the Siphoviridae family with icosahedral head and long non-contractile flexible tail. 
The name Siphoviridae comes from the Greek word Siphon which means tube referring to the long tail [22]. This family includes eight genera that are characterized by having long $(65-570 \times 7-10 \mathrm{~nm})$, noncontractile, thin tails which are often flexible and built of stacked disks of 6 subunits [22].

The newly isolated phages are virulent against a broad range of $S$. aureus isolates while most staphylococcal phages of this family are temperate phages detected as prophage or may have lytic activity due to mutation in the lysogeny functions [30,31]. However there are several Siphoviral phages with lytic activity against a wide range of $S$. aureus such as YMC/09/04/R1988 MRSA BP [32]. Other virulent phages against MRSA have been isolated such as SEW, M1M4, CJ11, CJ12, CJ16, CJ17, CJ18 and CF6 [33].

The three phages were susceptible to low $\mathrm{pH}$ levels of 1 and 2 while their susceptibility to $\mathrm{pH} 3$ varied. Phages are usually influenced by the acidity of the environment but some phages can withstand low $\mathrm{pH}$ environment $(\mathrm{pH} \leq 3.5)$ [34]. All three phages were stable within a wide $\mathrm{pH}$ range from 4-10 resembling other phages of Siphoviridae family such as the $\lambda$ phage [35]. $\phi S A 3$ was stable at a wider $\mathrm{pH}$ range (3-11) while $\phi S A 1$ and $\phi S A 2$ were stable at $\mathrm{pH}$ (4-10). Extremely high $\mathrm{pH}$ environments $(\mathrm{pH} \geq 12)$ were unfavourable for all three phages. The ability of these phages of Siphoviridae to survive such a wide range of $\mathrm{pH}$ make them suitable for oral administration as possible bacteriophagebased DNA vaccines as suggested by Jepson [35].

Interestingly, all three phages were refractory to digestion by endonuclease enzymes such as EcoRI and AccI. This phenomenon is referred to as an anti-restriction mechanism which is common among Siphoviridae phages [36,37]. There are several anti-restriction strategies by which phages can evade destruction by their bacterial host restriction systems [38]. These anti-restriction strategies include alteration of phage DNA sequence such as the loss of recognition sites in the phage genome for a particular endonuclease enzyme and the incorporation of unusual bases in the phage DNA making it insensitive to digestion by endonuclease enzymes, transient occlusion or blocking of restriction sites by phage encoded proteins, subversion of restriction-modification activities and direct inhibition of restriction enzymes by phage encoded anti-restriction proteins [38-41].

The molecular identification of the three phages showed remarkable results. A high degree of homology between the newly isolated virulent phages and their temperate ancestors was observed in which four genes all of temperate phage origins were detected. Therefore our data suggest that the genomes of these virulent phages have undergone recombination or horizontal gene transfer from a common genetic pool.

Such mosaicism has been reported several times among members of all three tailed phage families. Due to such mosaicism some lytic phages can be derived from temperate phages by rearrangement and deletion of lysogeny modules [42]. A virulent mycobacteriophage D29 appeared to be derived from the temperate phage L5 due to deletion resulting in $80 \%$ homology of their nucleotide sequences [43].

Certain staphylococcal phages encode virulence factors such as staphylococcal toxin which include staphylokinase (sak), enterotoxin A (sea), enterotoxin E (see), enterotoxin P (sep), exfoliative toxin A (eta), Panton-Valentine leukocidin (PVL), toxic shock syndrome toxin (tst), the innate immune modulators SCIN and CHIPS [44-46]. These toxins are responsible for a wide range of life threatening illnesses such as scalded-skin syndrome, food poisoning and toxic shock syndrome [44]. Since these toxins are harmful to mammalian cells it is important to ensure that they are not encoded by therapeutic phages. Based on the
PCR results, all three phages were unable to encode for enterotoxins (sea, seb, sec and see), exfoliating toxins (eta and etb) and the toxic shock syndrome toxin (tst). The absence of these genes from the phages needs to be ensured by further studies including complete genome sequencing and clinical trials to ensure their safety as an alternative therapeutic agent against MRSA.

In conclusion, the three isolated phages are highly effective against a wide range of methicillin resistant $S$. aureus isolates and have the ability to survive a $\mathrm{pH}$ range from 4-10. Moreover, these phages lacked genes for the staphylococcal enterotoxins although they show some similarity with their ancestors of the Siphoviridae family. The strong lytic activity of these phages against MRSA, the ability to withstand a wide $\mathrm{pH}$ range and the absence of toxin encoding genes all indicate that these Siphoviridae phages maybe a possible alternative for antibiotic therapy but further studies are required to assess their activity in clinical trials.

\section{Acknowledgment}

We acknowledge with a deep sense of gratitude, the support of the genetic engineering labs of College of Science at Al-Basra University (Iraq) as well as the support of College of Applied Biotechnology of Al-Nahrain University (Iraq), and Khajeh Nasir Toosi University of Technology (Iran) for imaging the bacteriophages. We would also like to express our gratitude to professor Carlton Gyles from University of Guelph, Canada for his valuable advice.

\section{References}

1. Liu C, Bayer A, Cosgrove SE, Daum RS, Fridkin SK, et al (2011) "Clinical practice guidelines by the Infectious Diseases Society of America for the treatment of methicillin-resistant Staphylococcus aureus infections in adults and children". Clinical Infectious Diseases 52: e18-55.

2. Fey PD, Saïd-Salim B, Rupp ME, Hinrichs SH, Boxrud DJ, et al. (2003) "Comparative molecular analysis of community-or hospital-acquired methicillinresistant Staphylococcus aureus". Antimicrob Agents Chemother 47: 196-203.

3. Lee JH (2003) Methicillin (Oxacillin)-Resistant Staphylococcus aureus Strains Isolated from Major Food Animals and Their Potential Transmission to Humans. Appl Environ Microbiol 69: 6489-6494.

4. Kaur S, Harjai K, Chhibber S (2012) "Methicillin-Resistant Staphylococcus aureus Phage Plaque Size Enhancement Using Sublethal Concentrations of Antibiotics". Appl Environ Microbiol 78: 8227-8233.

5. Plata K, Rosato AE, Wegrzyn G (2009) "Staphylococcus aureus as an infectious agent: overview of biochemistry and molecular genetics of its pathogenicity". Acta Biochim Pol 56: 597-612.

6. Costa AR, Batistão DWF, Ribas RM, Sousa AM, Pereira MO, et al. (2013) "Staphylococcus aureus virulence factors and disease". Microbial pathogens and strategies for combating them: science, technology and education, A. Méndez-Vilas, Formatex: Spain.

7. Pinchuk IV, Beswick EJ, Reyes VE (2010) "Staphylococcal Enterotoxins". Toxins 2: 2177-2197.

8. Kutter E, De Vos D, Gvasalia G, Alavidze Z, Gogokhia L, et al. (2010) "Phage Therapy in Clinical Practice: Treatment of Human Infections". Curr Pharm Biotechnol 11: 69-86.

9. Golkar Z, Bagasra O, Pace DG (2014) "Bacteriophage therapy: a potentia solution for the antibiotic resistance crisis". J Infect Dev Ctries 8: 129-136.

10. Rakhuba DV, Kolomiets El, Dey ES, Novik GI (2010) 'Bacteriophage receptors, mechanism of adsorption and penetration into host cell". Pol J Microbiol 59: 145-155.

11. Wittebole X, De Roock S, Opal SM (2014) "A historical overview of bacteriophage therapy as an alternative to antibiotics for the treatment of bacterial pathogens". Virulence 5: 226-235.

12. O'Flaherty S, Ross RP, Meaney W, Fitzgerald GF, Elbreki MF, et al. (2005) "Potential of the polyvalent anti-Staphylococcus bacteriophage $\mathrm{K}$ for control of antibiotic- resistant staphylococci from hospitals". Appl Environ Microbiol 71: 1836-1842.

13. Chhibber S, Gupta P, Kaur S (2014) "Bacteriophage as effective decolonising agent for elimination of MRSA from anterior nares of BALB/c mice". BMC Microbiol 14: 212. 
Citation: Mohammed-Ali MN, Jamalludeen NM (2015) Isolation and Characterization of Bacteriophage against Methicillin Resistant Staphylococcus aureus. J Med Microb Diagn 5: 213. doi:10.4172/2161-0703.1000213

14. Casjens SR, Thuman-Commike PA (2011) "Evolution of mosaically related tailed bacteriophage genomes seen through the lens of phage P22 virion assembly". Virology 411: 393-415.

15. Hendrix RW, Smith MCM, Burns RN, Ford ME, Hatfull GF (1999) "Evolutionary relationships among diverse bacteriophages and prophages: All the world's a phage". Proc Natl Acad Sci USA 96: 2192-2197.

16. Hatfull GF, Hendrix RW (2011) "Bacteriophages and their Genomes". Curr Opin Virol 1: 298-303.

17. Forbes BA, Sahm DA, Weissfeld AS (2007) "Bailey \& Scott's Diagnostic Microbiology". [12 ${ }^{\text {th }}$ edn], Mosby Elsevier Press: St. Louis, Missouri.

18. Broekema NM, Van TT, Monson TA, Marshall SA, Warshauer DM (2009) "Comparison of Cefoxitin and Oxacillin Disk Diffusion Methods for Detection of mecA-Mediated Resistance in Staphylococcus aureus in a Large-Scale Study". J Clin Microbiol 47: 217-219.

19. (2014) Clinical and Laboratory Standards Institute. "Performance Standards for Antimicrobial Susceptibility Testing; Twenty-Fourth Informational Supplement". CLSI document M100-S24, 34: 219.

20. Jamalludeen N, Johnson RP, Friendship R, Kropinski AM, Lingohr EJ, et al. (2007) "Isolation and characterization of nine bacteriophages that lyse O149 enterotoxigenic Escherichia coli”. Vet Microbiol 124: 47-57.

21. Sambrook J, Russell DW (2001) 'Molecular cloning: a laboratory manual”. [3 $3^{\text {rd }}$ edn], Cold Spring Harbor Laboratory Press: NY.

22. (2005) ICTV-International Committee on Taxonomy of Viruses. "Virus taxonomy; classification and nomenclature of viruses". Eighth report of the International Committee on Taxonomy of Viruses. Springer-Verlag/Wien, Austria 57-70.

23. Pantůček R, Doškař J, Růžičková V, Kašpárek P, Oráčová E, et al. (2004) "Identification of bacteriophage types and their carriage in Staphylococcus aureus". Arch Virol 149: 1689-1703.

24. Mehrotra M, Wang G, Johnson WM (2000)"Multiplex PCR for Detection of Genes for Staphylococcus aureus Enterotoxins, Exfoliative Toxins, Toxic Shock Syndrome Toxin 1, and Methicillin Resistance". J Clin Microbiol 38: 1032-1035.

25. Sandaa RA (2012) "Environmental viral pool”. In: Schmidt TM, Schaechter M (eds.) Topics in Ecological and Environmental Microbiology. USA. Elsevier Inc.

26. Mathur P (2011) "Hand hygiene: Back to the basics of infection control". Indian J Med Res 134: 611-620.

27. Międzybrodzki R, Fortuna W, Dabrowska BW, Górski A (2007) 'Phage therapy of staphylococcal infections (including MRSA) may be less expensive than antibiotic treatment". Postepy Hig Med Dosw 61: 461-465.

28. Lasobras J, Muniesa M, Lucena F, Jofre J (1997) "Relationship between the morphology of bacteriophages and their persistence in the environment". Water, Sci Tech 35: 129-132.

29. Muniesa M, Lucena F, Jofre J (1999) "Study of the potential relationship between the morphology of infectious somatic coliphages and their persistence in the environment". J Appl Microbiol 87: 402-409.

30. Deghorain M, Van Melderen L (2012) "'The Staphylococci Phages Family: An
Overview". Viruses 4: 3316-3335.

31. Xia G, Wolz C (2014) "Phage of Staphylococcus aureus and their impact on host evolution". Infect Gene Evol 21: 593-601.

32. Jeon J, D'Souza R, Hong SK, Lee Y, Yong D, et al. (2014) "Complete genome sequence of the Siphoviral bacteriophage YMC/09/04/R1988 MRSA BP: A lytic phage from a methicillin-resistant Staphylococcus aureus isolate". FEMS Microbiol Lett.

33. Jensen KC, Hair BB, Wienclaw TM, Murdock MH, Hatch JB, et al. (2015) "Isolation and Host Range of Bacteriophage with Lytic Activity against Methicillin-Resistant Staphylococcus aureus and Potential Use as a Fomite Decontaminant". PLoS ONE 10: e0131714.

34. Lu Z, Breidt F, Plengvidhya V, Fleming HP (2003) "Bacteriophage Ecology in Commercial Sauerkraut Fermentations". Appl Environ.Microbiol 69: 31923202.

35. Jepson CD, March JB (2004) "Bacteriophage lambda is highly stable DNA vaccine delivery vehicle". Vaccine 22: 2413-2419.

36. Barrangou R, Yoon S, Breidt $F$, Fleming $H$, Klaenhammer $T$ (2002)"Characterization of six Leuconostoc fallax bacteriophages isolated from an industrial Sauerkraut Fermentation". Appl Environ Microbial 68: 5452-5458.

37. Kęsik-Szeloch A, Drulis-Kawa Z, Weber-Dąbrowska B, Kassner J, MajkowskaSkrobek G, et al. (2013) "Characterising the biology of novel lytic bacteriophages infecting multidrug resistant Klebsiella pneumoniae". Virol J 10: 100.

38. Tock MR, Dryden DT (2005) "The biology of restriction and anti-restriction". Curr Opin Microbiol 8: 466-472.

39. Kovalchuk I, Kovalchuk O (2012) Epigenetics in health and disease. Pearson Education, Inc. FT press 402.

40. Pristas P, Vandzurova A, Javorsky P (2014) 'Interplay between bacteriophages and restriction-modification systems in enterococci". Nova Biotechnologica et Chimica 13: 13-20.

41. Vasu K, Nagaraja V (2013) "Divers functions of restriction-modification systems in addition to cellular defense". Microbiol Mol Boil Rev 77: 53-72.

42. Brüssow H, Desiere F (2001) "Comparative phage genomics and the evolution of Siphoviridae: insights from dairy phages". Mol Microbial 39: 213-222.

43. Summer EJ, Gonzalez CF, Bomer M, Carlile T, Embry A, et al. (2006 "Divergence and Mosaicism among Virulent Soil Phages of the Burkholderia cepacia Complex". J Bacteriol 188: 255-268.

44. Boyed EF (2012) "Bacteriophage-encoded virulence factors and phagepathogenicity island interactions". Adv virus Res 82: 91-118.

45. Brüssow H, Canchaya C, Hardt WD (2004) "Phages and the Evolution of Bacterial Pathogens: from Genomic Rearrangements to Lysogenic Conversion". Microbiol Mol Biol Rev 68: 560-602.

46. Christie GE, Matthews AM, King DG, Lane KD, Olivarez NP, et al. (2010) "The complete genomes of Staphylococcus aureus bacteriophages 80 and 80 -implications for the specificity of SaPI mobilization". Virol 407: 381-390. 